\title{
NANSEN MEDAL FOR MALAYSIAN RED CRESCENT
}

The Nansen Medal for 1977 was awarded, on 10 October, to the Malaysian Red Crescent Society by Prince Sadruddin Aga Khan, United Nations High Commissioner for Refugees and Chairman of the Nansen Medal Committee. The ceremony took place in Geneva, during the meeting of the Executive Committee for the UNHCR Programme, under the chairmanship of Mr. Winspeare Guicciardi, Director-General of the United Nations European Office, and in the presence of Mr. Eigil Nansen, representing the Norwegian Government. Many friends from the ICRC and the League of Red Cross Societies attended the presentation of the Medal to the Malaysian Red Crescent Society.

Mr. K. Waldheim, Secretary-General of the United Nations, sent a message, which was read out by the presiding chairman, paying tribute to the Malaysian Red Crescent and to its 40,000 members for their efforts in aiding thousands of refugees who arrived in their country in recent years as a result of the conflict in Indo-China.

The Malaysian Red Crescent Society was established a quarter of a century ago, and since then has served its community in the finest traditions that have characterized the efforts of its sister National Red Cross and Red Crescent Societies throughout the world. As a vital operational partner of the United Nations High Commissioner for Refugees, and in conjunction with governmental authorities and the Muslim Welfare Organization of Malaysia (PERKIM), it has provided humanitarian aid to the displaced persons and refugees who have recently arrived in Malaysia. It has actively promoted the local integration of those granted permission to settle in the country, while also continuing to provide aid to those granted temporary asylum pending permanent resettlement elsewhere. The award of the medal for 1977 to the Malaysian Red Crescent Society is a token of the international community's appreciation for its efforts on behalf of the dispossessed and homeless... 
The President of the Malaysian Red Crescent, Tunku Tan Sri Mohamed bin Tunku Besar Burhanuddin, who was accompanied by Datin Ruby Lee, the Society's General Secretary, received the Nansen Medal from the hands of the United Nations High Commissioner for Refugees. In his speech of thanks, the President stressed that the honour was conferred on all 40,000 members of his Society.

The whole Red Cross movement is extremely pleased with the distinction won by the Malaysian Red Crescent Society, and expresses its warm congratulations.

\section{THE RED CROSS TEACHING GUIDE}

The Red Cross Teaching Guide is an educational manual designed for secondary school teachers throughout the world. It is presented in the form of a collection of separate papers on a number of subjects, put together in a cardboard box-folder. Each one contains an explanatory text on the subject dealt with, one or two texts for reading (chosen, for example, from the works of Henry Dunant) or a narrative (often describing a mission carried out by an ICRC delegate), statistics (on Red Cross relief distribution, etc.), maps and photographic illustrations. Apart from these texts and documents, the files and dossiers give explanations and suggestions for the way the teacher can take up a particular topic in the classroom, as part of a course on one of a wide variety of subjects, such as history, geography, mathematics, etc., and help him or her to find facts and references that can be introduced into the teaching.

Each paper can be adapted to the special needs and circumstances of the country in which the guide is to be used, and National Societies may insert such modifications and additions as they consider necessary, on the pages that have been left blank. 